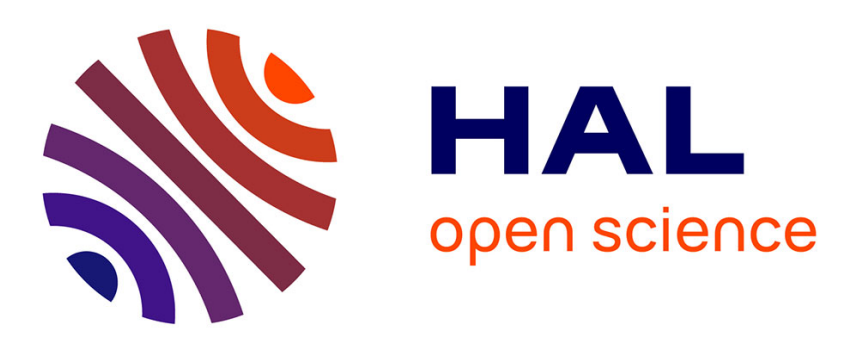

\title{
Coating behaviour for materials of industrial waste incinerators and heat exchangers in high temperature corrosive atmospheres
}

F. Devisme, T. Flament, J. Mulet, C. Prebende, J. Martigneaux

\section{- To cite this version:}

F. Devisme, T. Flament, J. Mulet, C. Prebende, J. Martigneaux. Coating behaviour for materials of industrial waste incinerators and heat exchangers in high temperature corrosive atmospheres. Journal de Physique IV Proceedings, 1993, 03 (C9), pp.C9-771-C9-778. 10.1051/jp4:1993980 jpa-00252422

HAL Id: jpa-00252422

https://hal.science/jpa-00252422

Submitted on 1 Jan 1993

HAL is a multi-disciplinary open access archive for the deposit and dissemination of scientific research documents, whether they are published or not. The documents may come from teaching and research institutions in France or abroad, or from public or private research centers.
L'archive ouverte pluridisciplinaire HAL, est destinée au dépôt et à la diffusion de documents scientifiques de niveau recherche, publiés ou non, émanant des établissements d'enseignement et de recherche français ou étrangers, des laboratoires publics ou privés. 


\title{
Coating behaviour for materials of industrial waste incinerators and heat exchangers in high temperature corrosive atmospheres
}

\author{
F. Devisme $\left({ }^{1}\right)$, T. Flament $\left({ }^{1}\right)$, J.C. $\operatorname{Mulet}\left({ }^{2}\right)$, C. Prebende $\left({ }^{2}\right)$ and J.L. Martigneaux $\left({ }^{3}\right)$ \\ (1) CEA/DTA/CEREM/DTM/SCECF, Centre d'Etudes de Fontenay-aux-Roses, 60-68 Avenue \\ du Général Leclerc, B.P. 6, 92265 Fontenay-aux-Roses Cedex, France \\ $\left({ }^{2}\right)$ BERTIN et Cie, Centre de Bayonne, Zone Industrielle, 40220 Tarnos, France \\ $\left({ }^{3}\right)$ GEREP S.A. Zone industrielle de Mitry-Compans, rue Jacquard, 77290 Mitry-Mory, France
}

\begin{abstract}
A coating obtained by flame spraying (Ni-Al) and an aluminizing type (Sermaloy J) were tested in laboratory and in industrial waste incinerator (substrate: AISI 310 steel). In laboratory tests, the studied parameters were: $\mathrm{HCl}$-content ( 1 and $3 \%$ vol. in air $+0.1 \%$ vol. $\left.\mathrm{SO}_{2}\right)$, temperature $\left(600\right.$ and $\left.800^{\circ} \mathrm{C}\right)$ and thermal cycling between 800 and $400^{\circ} \mathrm{C}$. The increasing of the temperature and $\mathrm{HCl}$-content, and also thermal cycling lead to a degradation of the non coated steel and Ni-Al coated specimen behaviours; as for Sermaloy J, only temperature raising seems to have a detrimental effect (first batch). For the field tests, the specimens were exposed at about $600{ }^{\circ} \mathrm{C}$ in flue gases containing about $0.4 \%$ vol. $\mathrm{HCl}$ and flying ashes (sodium chloride and sulfate); the corrosion phenomena are more closed to molten salts interactions than to gaseous corrosion: Ni-Al behaves better compared with Sermaloy J and the non coated steel which are much more attacked than in laboratory. However, Sermaloy J and Ni-Al can lead to a real protection of a steel substrate but the manufacturing conditions have a great influence on the behaviour of the coated specimens.
\end{abstract}

\section{Introduction.}

Metallic materials are often severely attacked in the high temperature $\left(600-800{ }^{\circ} \mathrm{C}\right)$ corrosive atmospheres encountered in industrial waste incinerators especially when the chlorine content in the waste is high. A thermodynamical study was carried out [1-3] and showed that, among all oxides forming on high temperature alloys, alumina presents the largest domain of stability in oxichlorinating and oxisulfidizing atmospheres. However, because alumina forming alloys are not a good solution in the $600-800^{\circ} \mathrm{C}$ intermediate temperature range, an aluminium rich coating could be a promising way to reduce the alteration of the materials. So, a joint research programme has been undertaken in that field by CEA, BERTIN and GEREP.

Four coatings used particularly in aeronautical industry and whose implementation could be technically compatible with the construction of industrial incinerators, were selected: $\mathrm{Ni}-\mathrm{Al}$ (oxyacetylene gun and wire, 20wt\% Al; porosity about 8-10\%), NiCrAlY (atmospheric spraying gun and powder; wt $\%$ : $22 \mathrm{Cr}-10 \mathrm{Al}-1 \mathrm{Y}$; porosity about $5 \%$ ), $\mathrm{Al}_{2} \mathrm{O}_{3}$ (with 1 wt $\% \mathrm{SiO}_{2}$; porosity about $8 \%$ ) on NiCoCrAlY underlayer (wt \%: $17.5 \mathrm{Cr}-2.5 \mathrm{Co}-5.5 \mathrm{Al}-0.5 \mathrm{Y}$, both atmospheric spraying gun and powder) and Sermaloy $\mathrm{J}(30 \mathrm{wt} \% \mathrm{Al}$, aluminizing type coating with diffusion treatment between 900 and $1050^{\circ} \mathrm{C}[4,5]$; the suppliers were Turbomeca for the three first coatings and Heurchrome fot the last one. AISI 310S type steel (7 RE 10 supplied by Sandvik, with $1.28 \mathrm{wt} \% \mathrm{Si}$ and $0.1 \mathrm{Ce}$ ), was chosen as substrate because of its good mechanical properties in the $600-800{ }^{\circ} \mathrm{C}$ temperature range, and also for its cost. 
In a first step, laboratory screening tests were carried out on all the materials. Two coatings revealed a poor behaviour at $800^{\circ} \mathrm{C}$ : complete destruction of NiCrAlY (coating thickness: 480-550 $\mu \mathrm{m}$ ) and scaling of $\mathrm{Al}_{2} \mathrm{O}_{3}$ (alumina thickness: $400-560 \mu \mathrm{m}$ ); so, they were given up for the continuation of the study.

As for the two other coatings (Ni-Al and Sermaloy J), their behaviour and the substrate one were characterized in laboratory tests and during exposure in the GEREP incinerator. The results obtained are presented in this paper.

\section{Experimental.}

2.1 EXPERIMENTAL DEVICES. - For laboratory tests, carried out by CEA, the Coralline rig was used; it is composed of eight independant test sections (open circuit) where the specimens (only one type of material per test section) are leached by the gas.

As for the GEREP incinerator, it burns chlorinated liquid wastes (average Cl-content: about $7 \mathrm{wt} \%)$. The specimens were located between the postcombustion chamber and the off-gas neutralization system.

2.2 OPERATING CONDITIONS: - For each laboratory tests, the exposure duration was 500 hours and the total flow rate was $151 . \mathrm{h}^{-1}$ (at $20^{\circ} \mathrm{C}$ ) under atmospheric pressure. The studied parameters were (see Tab. I): $\mathrm{HCl}$-content ( 1 and $3 \%$ vol. in air $+0,1 \%$ vol. $\mathrm{SO}_{2}$ ), temperature $\left(600\right.$ and $800^{\circ} \mathrm{C}$ ) and thermal cycling (hold temperature: $800^{\circ} \mathrm{C}$; for one hour per day down to $400^{\circ} \mathrm{C}$ ). For the field tests, the specimens were exposed at about $600^{\circ} \mathrm{C}$ during 800 hours and under a flue gas rate of $35000 \mathrm{Nm}^{3} \mathrm{~h}^{-1}$ containing about $0.4 \%$ vol. $\mathrm{HCl}$ and flying ashes mainly constituted of sodium chloride and sulfate, as shown by analysis.

2.3 MATERIALS PREPARATION AND CHARACTERIZATION. - The non coated steel was ground with SiC 600 paper while the coated specimens were just cleaned with solvent; weight and dimensions were measured.

All materials were characterized before and after test by cross-section optical micrographic examination. Analysis were performed by SEM/EDS or electron microprobe and X-ray diffraction. Before test, the $\mathrm{Ni}-\mathrm{Al}$ coating seemed well adherent to the substrate and did not present cracks. Besides, a cold-worked zone was observed on the steel side near the coating interface, probably due to the sand-blasting carried out before coating operation. The thickness of Ni-Al was not regular because of manual operation (Fig. 1) and especially for the second batch for which the deposit was thinner and more porous on edges: $340-650 \mu \mathrm{m}$ for the first batch and, for the second one, $330-570 \mu \mathrm{m}$ on large sides and less than $200 \mu \mathrm{m}$ on the edges. As for Sermaloy J, almost the same features and very regular thicknesses were observed for the two batches; the coating can be divided in 3 main zones (Figs. 2 and 3): external zone (irregular profile, maximal thickness $40 \mu \mathrm{m}$; wt $\% 22.5 \mathrm{Al}-6.7 \mathrm{Cr}-15.6 \mathrm{Ni}-49.5 \mathrm{Fe}$ ), intermediate zone (about $15 \mu \mathrm{m}$; Ni-Al rich barrier, wt\%: 26.6Al-2.2Cr-57.5Ni-11.3Fe) and internal zone (about $55 \mu \mathrm{m}$; wt\%: 2.0Al-28.2Cr-11.6Ni-52.1 Fe).

\section{Results of tests.}

Table I reports the main micrographic measurements for all the tests, in terms of maximal thickness loss of sound metal per side. 


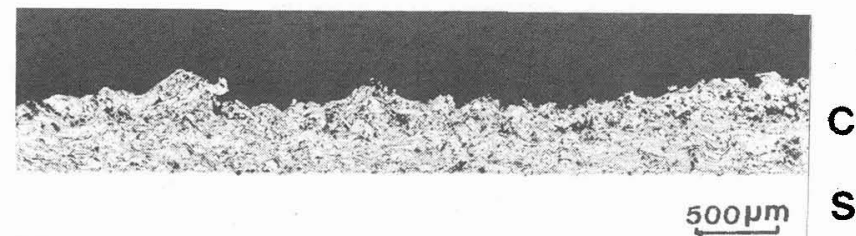

Fig. 1. - Cross section optical micrograph of a $\mathrm{Ni}-\mathrm{Al}$ coated specimen before test $(\mathrm{C}=$ coating, $\mathrm{S}=$ substrate).

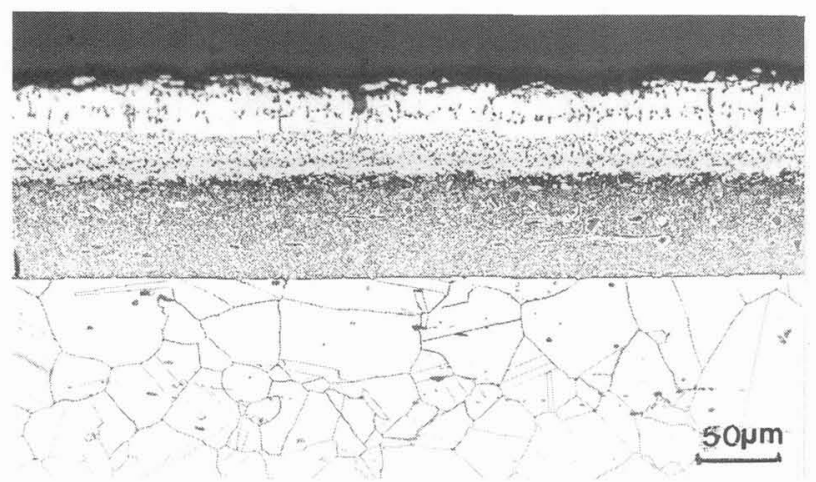

Fig. 2.

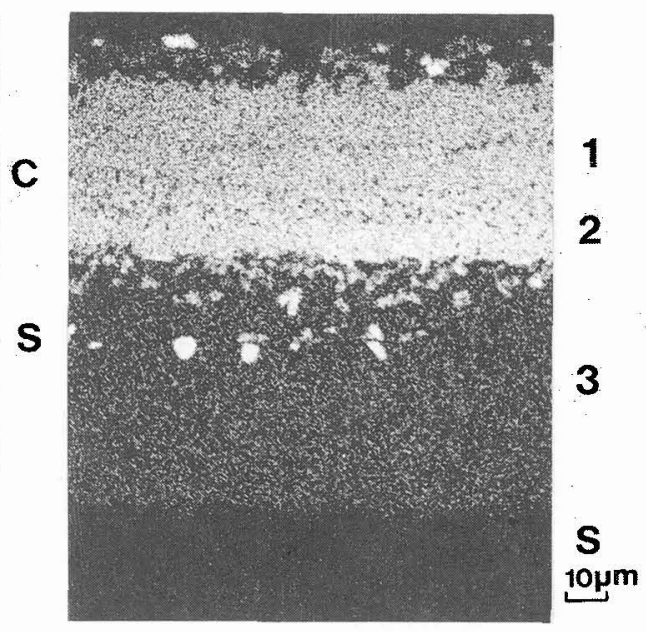

Fig. 3.

Fig. 2. - Cross section optical micrograph of a Sermaloy J coated specimen before test (electrolytic attack; $\mathrm{C}=$ coating, $\mathrm{S}=$ substrate).

Fig. 3. - X-image of aluminium (electron microprobe) showing the diffusion zones of Sermaloy $\mathrm{J}$ coating on steel before test $(1=$ external zone; $2=$ intermediate zone; $3=$ internal zone; $S=$ substrate $)$.

3.1 NON COATED STEEL. - In the laboratory tests, at $600^{\circ} \mathrm{C}$, the steel suffers only a slight attack and is covered by a chromia layer. On the other hand, the corrosion at $800{ }^{\circ} \mathrm{C}$ is characterized by a general attack with an underlying $\mathrm{Cr}$-depleted zone and the formation of numerous cavities (Fig. 4); oxides mixtures $\left(\mathrm{Cr}_{2} \mathrm{O}_{3}, \mathrm{NiO},(\mathrm{Cr}, \mathrm{Fe})_{2} \mathrm{O}_{3}\right)$ and also $\mathrm{NiCl}_{2}$ are covering the surface. Under thermal cycling, the loss of sound metal is split up in general attack $(400 \mu \mathrm{m})$ and intergranular penetration underneath (Fig. 5). In the field tests, the steel undergoes only an intergranular attack with grain loosening (Fig. 6).

For the tests at $800^{\circ} \mathrm{C}$, sigma phase is observed in the grains and at the grain boundaries; the same phenomenon is also observed with the coated specimens.

3.2 Ni-Al COATING. - This coating does not seem to be attacked in all the tests and is covered by an alumina layer. However, a quite important scaling occurs with the second batch but, in the non scaled areas, oxides are present at the substrate interface and an intergranular attack, whose depth depends on experimental conditions (see Tab. I) is observed in the steel (Figs. 7, 8 and 9). 
Table I. - Results of metallographic measurements.

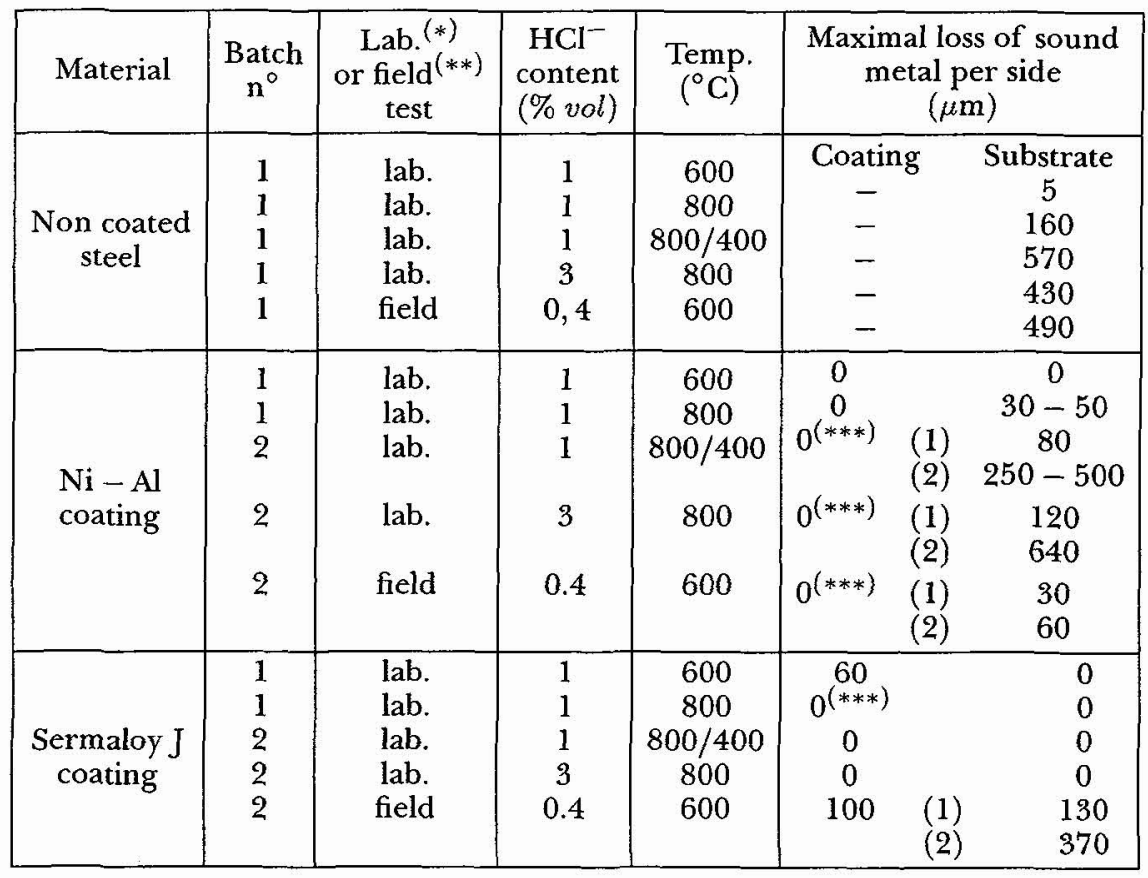

(*) 500 hours.

$(\star \star) ~ 800$ hours.

$(\star \star \star)$ partial scaling.

(1) areas where the coating is adhering and complete.

(2) scaled areas and edges.

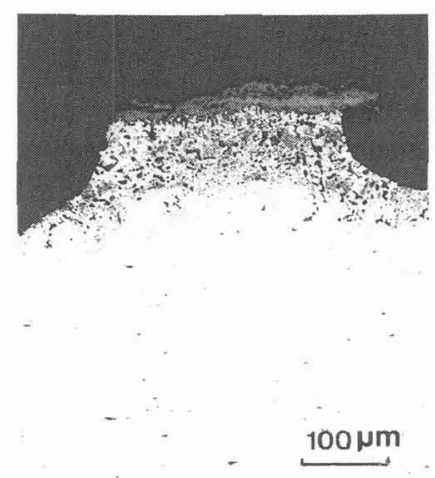

Fig. 4.

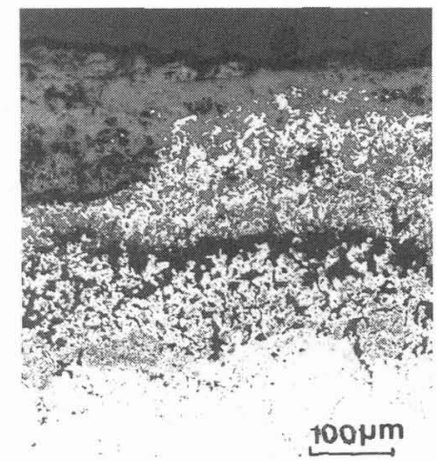

Fig. 5.

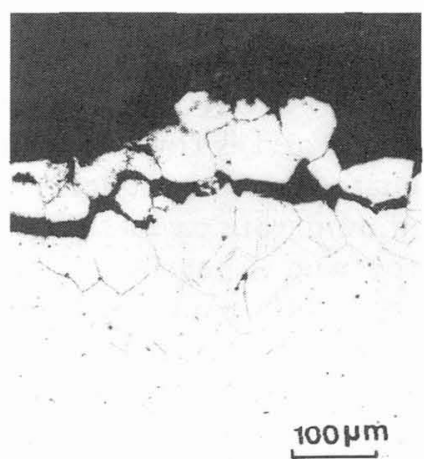

Fig. 6.

Fig. 4. - Cross section optical micrograph of a non coated steel specimen after laboratory test at $800^{\circ} \mathrm{C}$ (constant) with $1 \% \mathrm{HCl}$.

Fig. 5. - Cross section optical micrograph of a non coated steel specimen after laboratory test with thermal cycling.

Fig. 6. - Cross section optical micrograph of a non coated steel specimen after field test at $600{ }^{\circ} \mathrm{C}$. 
3.3 SERmaloy J COATING. - As for the Sermaloy J coating, at $600^{\circ} \mathrm{C}$, the external zone is covered with an irregular alumina layer but presents cavities and suffers an internal oxidation (Fig. 10), mainly of Fe concentrated along the grain boundaries, with an Al-depletion in the grains. At $800^{\circ} \mathrm{C}$, a partial scaling of the external zone is observed (Figs. 11 and 12) and an electron microprobe examination reveals that aluminium diffuses, on one hand, from the external zone to form an alumina layer on the surface and, on the other hand, from the intermediate zone towards the substrate where the Al-content is twice as high as before test. In the field tests, in some areas, the coating has completely disappeared and, where it is still present, it undergoes a general attack with cavities (Fig. 13) which, in some cases, penetrate the substrate.

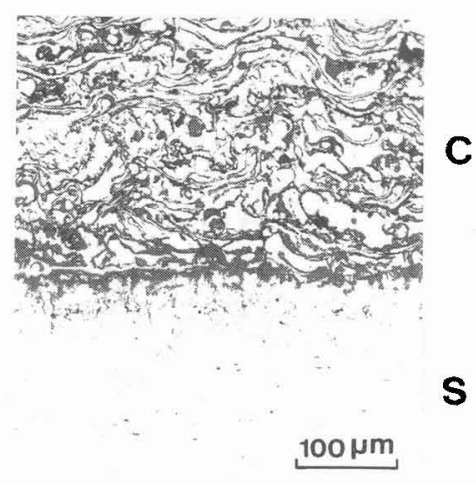

Fig. 7.

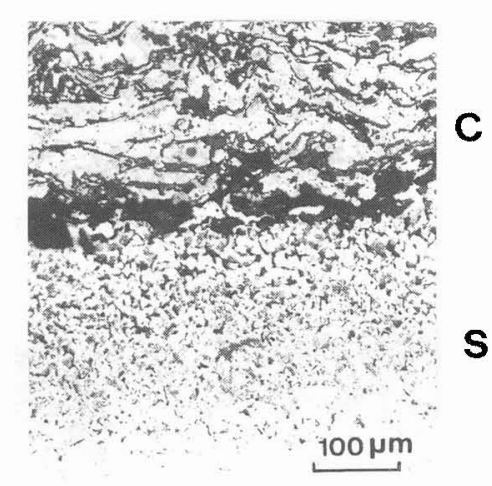

Fig. 8 .

Fig. 7. - Cross section optical micrograph of a NiAl coated specimen after laboratory test with thermal cycling (middle of large side; $\mathrm{C}=$ coating, $\mathrm{S}=$ substrate).

Fig. 8. - Cross section optical micrograph of a NiAl coated specimen after laboratory test with thermal cycling (edge; $\mathrm{C}=$ coating, $\mathrm{S}=$ substrate).

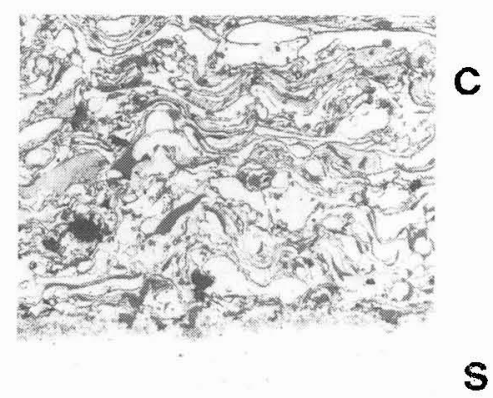

$100 \mu \mathrm{m}$

Fig. 9. - Cross section optical micrograph of a NiAl coated specimen after field test at $600{ }^{\circ} \mathrm{C}(\mathrm{C}=$ coating, $\mathrm{S}=$ substrate). 


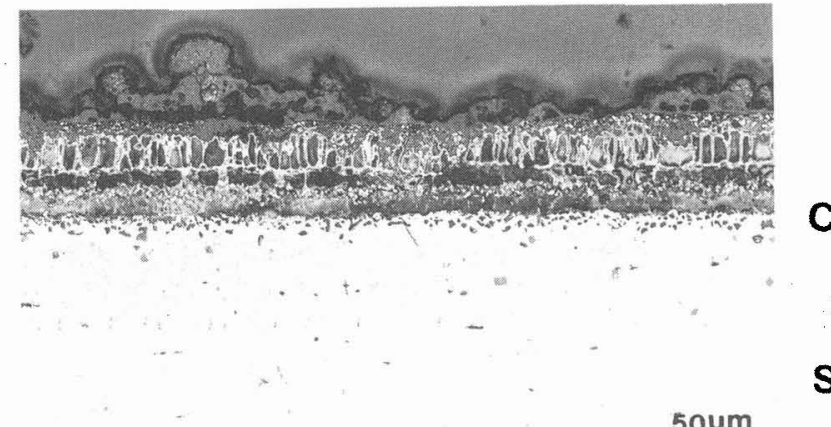

5opm

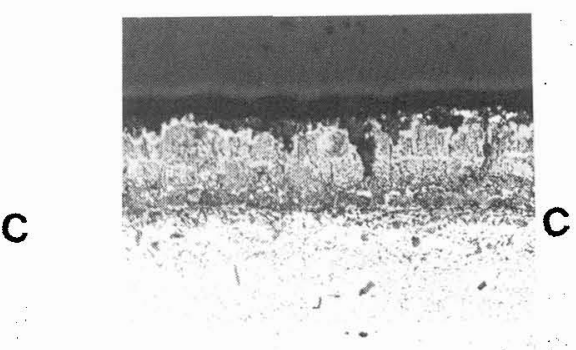

S

S

50 um

Fig. 10 .

Fig. 11 .

Fig. 10. - Cross section optical micrograph of a Sermaloy $J$ coated specimen after laboratory test at $600{ }^{\circ} \mathrm{C}$ with $1 \% \mathrm{HCl}(\mathrm{C}=$ coating, $\mathrm{S}=$ substrate $)$.

Fig. 11. - Cross section optical micrograph of a Sermaloy J coated specimen after laboratory test at $800^{\circ} \mathrm{C}$ (constant) with $1 \% \mathrm{HCl}$ : external zone present $(\mathrm{C}=$ coating, $\mathrm{S}=$ substrate).

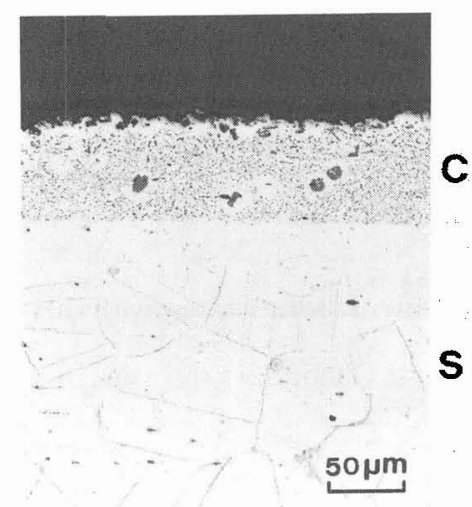

Fig. 12.

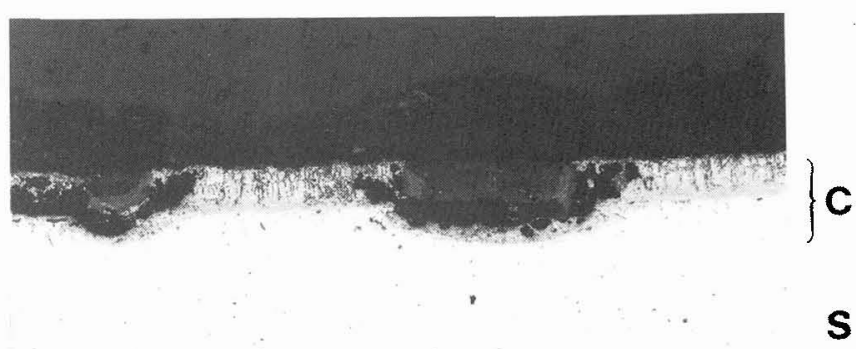

$100 \mu \mathrm{m}$

Fig. 13.

Fig. 12. - Cross section optical micrograph of a Sermaloy J coated specimen after laboratory test at $800{ }^{\circ} \mathrm{C}$ (constant) with $1 \% \mathrm{HCl}$ : external zone scaled $(\mathrm{C}=$ internal zone of the coating, $\mathrm{S}=$ substrate). Fig. 13. - Cross section optical micrograph of a Sermaloy J coated specimen after laboratory test at $600^{\circ} \mathrm{C}(\mathrm{C}=$ coating, $\mathrm{S}=$ substrate $)$.

\section{Discussion.}

4.1 INFLUENCE OF TEMPERATURE. - The important increase (factor 30) of the corrosion rate of non coated steel can be attributed to the very important increase of the metallic chlorides vapor pressure between 600 and $800^{\circ} \mathrm{C}$ [2,6-8]. This phenomenon has already been observed with other alloys [1].

For $\mathrm{Ni}-\mathrm{Al}$ coated specimens, the increase from 600 to $800^{\circ} \mathrm{C}$ induces a slight internal attack at the steel-coating interface, probably due to the relatively high porosity of the layer. 
As for Sermaloy $\mathrm{J}$ coating, it seems that the temperature raising from 600 to $800{ }^{\circ} \mathrm{C}$ has increased the scaling of the external zone and this phenomenon can perhaps be related to the diffusion of aluminium detailed in 3.3.

4.2 INFLUENCE OF THERMAL CYCLING. - The comparison of the results obtained with non coated steel clearly shows the detrimental effect of thermal cycling at $800^{\circ} \mathrm{C}$ (factor 3) [3].

For $\mathrm{Ni}-\mathrm{Al}$ coated specimens, the important scaling observed during the test can be either attributed to the effect of mechanical stress induced by thermal cycling or to the poor quality of the coating delivered for the second batch. However, in the still adhering areas, the attack observed at the coating interface is also higher after thermal cycling. So, this phenomenon which results from the porosity of the coating, would have led sooner or later to a scaling in presence of thermal cycling.

Finally, the very good behaviour of Sermaloy J after thermal cycling (no attack) can certainly be related to the quality of the alumina layer covering the external interface and also to the bonding of the coating on the steel by a diffusion zone.

4.3 INFLUENCE OF HCl-CONTENT. - The comparison of the tests carried out with 1 and $3 \%$ $\mathrm{HCl}$, demonstrates the influence of this parameter on the corrosion rate of the non coated $310 \mathrm{~S}$ steel. This is in accordance with previous observations [1], which showed that the corrosion of various alloys by $\mathrm{HCl}$ containing gases was often controlled by the diffusion of $\mathrm{HCl}$ to the interface.

For Ni-Al coated specimens, an important scaling is observed in the $3 \% \mathrm{HCl}$ test. As discussed previously, this phenomenon can be attributed to the poor quality of the coating or to the attack at the steel-coating interface resulting from the porosity, which can lead to a scaling.

The Sermaloy $\mathrm{J}$ is not corroded at $800{ }^{\circ} \mathrm{C}$ with $3 \% \mathrm{HCl}$, which clearly demonstrates the improvement that can be obtained with this coating even in this very aggressive environment.

4.4 COMPARISON OF LABORATORY TESTS WITH FIELD TEST. - As pointed out by the important quantities of ashes surrounding the specimens, the corrosion conditions are completely different in the two types of tests, even if the chloride contents of the atmospheres are of the same order of magnitude. So, in the field test, the corrosion phenomena are more close to molten salts interactions than to gaseous corrosion. In that case, the important porosity of $\mathrm{Ni}-\mathrm{Al}$ is not so detrimental than in laboratory tests. In fact, no sulfate or chloride have been found in the coating and this is probably the reason for the better behaviour of $\mathrm{Ni}-\mathrm{Al}$ in field tests compared with the other materials.

The corrosion suffered by the Sermaloy J coating seems to show that the thin layer of alumina is not sufficient to resist the fluxing resulting from the presence of chlorides and sulfates [5].

As for the steel behaviour, its corrosion rate is much higher in the field test (factor 100) and it seems to demonstrate that the chromia layer formed at the surface is much more easily dissolved in molten salts than an alumina type layer.

\section{Conclusion.}

This study has shown that Al-rich coatings, such as Sermaloy J and Ni-Al, can lead to a real protection of a steel substrate, in oxichlorinating atmospheres and also in presence of molten sulfates and chlorides. However, this study has also pointed out the important influence of 
the manufacturing conditions on the behaviour of the coated specimens (unperfect reproducibility between batches, irregular thickness due to manual operation, porosity of Ni-Al).

If in clean atmosphere laboratory tests, $\mathrm{SO}_{2}$ has no noticeable influence in the corrosion process compared with $\mathrm{HCl}$ [7], on the contrary, sulfur oxides, leading to formation of sulfates in presence of alkaline compounds (field tests), can lead to very different phenomena $[5,9]$. So, taking into account the promising results obtained with $\mathrm{Ni}-\mathrm{Al}$ and Sermaloy J, the study should be extended with a particular attention paid to the following parameters: optimization of the coating processes (automatic operation, decrease in the Ni-Al porosity by powder spraying and surface remelting, evaluation of pack cementation for aluminizing) [5], behaviour in gas-molten salts environments, technical and economical comparisons of coatings to high temperature alloys.

\section{Acknowledgements.}

This work was carried out in the frame of a French research programme supported by the Ministry of Research and Technology, the CEA and BERTIN. The authors wish to thank MRT and CEA authorities for giving them the possibility of conducting this research and publishing the results. They are grateful to their colleagues of the European programme COST 501/WP4, for the fruitful discussions held with them, and to Sandvik Company for the free supply of the steel. The authors are also grateful to P. Falgoux for his participation in carrying the tests and to L. Heux, C. Mallet, P. Olivier and P. Perodeaud for the micrographic and analysis parts of this study.

\section{References}

[1] Devisme F., Falgoux P., Lefebvre F., Flament T., $30^{\text {èmes }}$ Journées du Cercle d'Etudes des Métaux, Bull. Cercle Etud. Mét. XVI (1) (1991) paper 14.

[2] StotT F.H., PreScott R., Elliott P., Al'Atia M.H.J.H., High Temp. Technol. 6 (1988) 115 .

[3] Stott F.H., Prescott R., Elliott P., Mater. Sci. Technol. 6 (1990) 364.

[4] MaZars P., MANeSSE D., Leroy M., Traitements de Surface et Protection contre la Corrosion, Ecole d'été, S. Audisio, M. Caillet, A. Galerie, H. Mazille Eds. (Aussois, 1987) (Les Editions de Physique, 1989) pp. 319-335.

[5] Hocking M.G., VASANTASReE V., SidkY P.S., Metallic and Ceramic Coatings: Production, High Temperature Properties and Applications (Longman Scientific and Technical, 1989).

[6] Daniel P.L., RapP R.A., Advances in Corrosion Science and Technology, Halogen Corrosion of Metals, Vol. 5, M.G. Fontana, R.W. Staehle Eds. (Plenum Press, 1976).

[7] CHANG Y.-N., WEI F.-I., J. Mater. Sci. 26 (1991) 3693.

[8] IhaRa Y., SAKIYAma K., HaShimoto K., Proc. JIMIS-3: High Temperature Corrosion, Trans. J. Inst. Met., Supplement (1983).

[9] VAughan D.A., KrauSE H.H., BoYD W.K., Ash Deposits and Corrosion from Impurities in Combustion Gases, R. Byers Ed. (Henniker, New Hampshire, 1977) p.473. 